\title{
Exploring the Relationship between Transportation Infrastructure and Regional Economic Growth Using Lösch's Location Theory
}

\author{
Cristiano Farias Almeida ${ }^{1}$, Francisco Gildemir Ferreira da Silva ${ }^{2} \&$ Paulo Henrique Cirino Araújo ${ }^{3}$ \\ ${ }^{1}$ Graduate Program Project and City, Federal University of Goias, Goiânia, Brazil \\ ${ }^{2}$ Economy Graduate Program, Federal University of Ceara, Fortaleza, Brazil \\ ${ }^{3}$ Transport Engineer, Federal University of Goias, Aparecida de Goiânia, Brazil \\ Correspondence: Cristiano Farias Almeida, Graduate Program Project and City, Federal University of Goias, \\ Goiânia, Brazil. Tel: 55-91-9-9132-9191. E-mail: cristianofarias@ufg.br
}

Received: March 26, 2021

doi:10.5539/jsd.v14n3p168
Accepted: May 2, $2021 \quad$ Online Published: May 14, 2021

URL: https://doi.org/10.5539/jsd.v14n3p168

\begin{abstract}
There are some knowledge gaps regarding the relationship between transportation infrastructure and economic development, especially about economic impacts that occur due to implementation of infrastructure in a given region, albeit various studies have addressed the issue. This paper aims to identify variables that affect economic development in order to contribute to the development of a theoretical model that could explain the relationship between transportation infrastructure and economic development. The theoretical model is satisfactory because it begins by analyzing the actions generated by the transportation infrastructure. Moreover, the model is based on the Location Theory considering the economic development and taking into account variables such as transportation costs, gain, product value, consumption, competition between companies and lastly monopoly. Finally, an econometric procedure, Spatial Panel Auto Regressive Vector Model (PVAR), was used to evaluate the relationship between economic development and investments in transportation infrastructure.
\end{abstract}

Keywords: transportation infrastructure, economic growth, economic development, Lösch's Location Theory, Spatial Panel Auto Regressive Vector Model

\section{Introduction}

The body of knowledge on transportation has gaps regarding how transportation infrastructure influences economic development, especially about the economic impacts that occur due to the building of infrastructure in a given region. Those impacts have not been measured or characterized. However, understanding this topic in detail is essential to develop public policies and guidelines on how investments in infrastructure should be conducted given that investing in transportation infrastructure usually increases a region's level of socioeconomic development. In addition, the natural resources available in a region as well as its productive capacity should be taken into account when devising a regional plan for investment.

As Brazil is a country of continental dimensions, the transportation sector is especially important because it is responsible for conveying both raw materials (inputs) and final goods (outputs) across great distances before they reach their destination (Araújo, 2006). Furthermore, when transportation infrastructure makes use of the natural resources available, the cost of conveying goods is greatly reduced. Unfortunately, from a historical perspective, Brazil has not been able to devise investment plans to provide efficient means of transportation that are coherent with the existing natural resources in each region. The country has continually failed to exploit its full productive capacity (Théry \& Mello, 2005).

Along with the investment governance failure, ever fewer investments in the transportation sector have been made over the years. Filho et. al. (1999) analyzed both the investment and funding of transportation infrastructure in Brazil between the years of 1999 and 2002. Such analyses show that the State's financial inability, added to the government's change of agenda increased the tendency to fall of investments in infrastructure. Investments were as high as $12 \%$ of the country's GDP in 1982, but only 1.1\% in 1998 (Araújo, 2006).

Studying the relationship between transportation and economic development is even more valuable in countries with budget constraints, not only to guide new interventions in transportation planning, but also because the resources used to build new transportation infrastructure have very high opportunity costs, given that they could 
be used in public policies that would offer better socioeconomic results (Magalhães, 2006). Developing projects to minimize the costs of transportation infrastructure can have significant impacts on the population's standard of living because they would benefit from the improvement of roads and means of transportation in general. In addition, production costs would be greatly reduced and this would also benefit the society as a whole. Moreover, this surplus capital could be indirectly invested in education, health, etc.

Additionally, there is another important factor regarding the relationship between the investment in transportation infrastructure and the population's quality of life, which is the modification of space: it becomes much more efficient by means of having better roads, which allow for faster transportation as well as airports with greater capacity and more terminals. Those factors influence where companies choose to make investments as well as their production and consumption decisions. Thus, they influence trade flows and the costs of trade relationships (Araújo, 2006).

Therefore, this study aims to investigate the relationship between transportation infrastructure and economic development by means of a theoretical model and to provide guidelines for investments in the transportation sector so as to achieve higher productivity levels and a higher standard of living. It is assumed that the relationship between transportation infrastructure and economic development is dialectical, i.e., such relationship works in both ways, insofar as increase in economic growth requires more transportation infrastructure and vice versa. However, this paper proposes to address only one direction of that relationship.

In order to contribute to the development of the theoretical model, Lösch's Location Theory served as a basis for this study because his theory works with concepts that are directly connected to transportation issues, especially the ones dealing with transportation costs. In addition, concepts regarding transportation infrastructure and economic development are used to provide theoretical support for the model.

\section{Literature Review}

Being familiar with some concepts as well as how they relate to each other and understanding the history of how thinking on this subject has developed is crucial for building a theoretical model. Thus, this section covers the main concepts regarding transportation and economic development; and Lösch's Location Theory, which provides a theoretical basis for the model proposed here.

\subsection{Economic Growth and Regional Economic Growth}

Countries' economic growth has been the subject of academic studies since the beginning of the last century. Economic growth is a process of constant improvement regarding a set of values carried out by the population of a given area (Colman \& Nixon, 1981; Lanzana, 2004). However, the values are determined by specialists, which make it a broad concept. Factors such as education, public and private investment and reducing the bureaucracy of State mechanisms explain the phenomenon to a greater or lesser degree (see Romer (1986 and 1990); Lucas (1990); Dasgupta and Stiglitz (1988); Aschauer (1989)). The basis of all those studies is the neoclassical theory of economic growth and its precursors (Ramsey, 1928; Solow, 1956; Swan, 1956; Arrow, 1962; and Uzawa, 1965). Aschauer in his work (Aschauer (1988 and 1989a-d)) discusses improving the efficiency of public investments. In recent decades, many researchers have dedicated themselves to proving the empirical validity of theoretical models, notably, Calderón et al. (2003); Calderón and Servén (2003); Ferreira and Maliagros (1998).

Although there are several theoretical and empirical studies, the contribution of specific sectors to economic growth remains to be understood, as investing in transportation infrastructure generates different externalities and spillover effects than those generated by investments in telecommunications or energy. Aschauer (1989a) says that investment in infrastructure increases economic and regional growth, and if transportation is necessary for the physical connection of regions, then it is logical to think that creating, expanding and maintaining transportation infrastructures, be they highways, railways, ports, canals or navigable rivers, are sources of economic growth.

The discussion around regional economic growth became more important in the late twentieth century driven by new explanatory theories that resulted from the development of globalization. Nevertheless, these theories often have different interpretations and are sometimes contradictory, thus, leaving plenty of room for constant debate (Cunha et. al., 2008).

\subsection{Transportation Infrastructure and Regional Economic Growth}

The issue of the impacts investments in transportation infrastructure can have on development, particularly on a regional or local scale, continues to be the object of investigation by transportation planners and scholars, with few consensual points and many uncertainties (Barros, 2006). 
Haynes (1997) states that investments in transportation infrastructure cause both short and long-term impacts on local economies. There is still little research on topics such as the dimension of productivity yields, the intensity and sustainability of production growth, and the improvement of regional competitiveness, which remain a vast field for studies and research projects (Barros, 2006). On the other hand, according to Quinet (1992), the possibility of no impact taking place is unlikely and rare. In fact, recent studies suggest that, as the economic space becomes more sophisticated, and consequently there is better transportation infrastructure, the intensity of impacts, from a socioeconomic perspective, go in the opposite direction, gradually becoming weaker. It has been observed that in developed economies for example, impacts are tiny, sometimes even imperceptible, given that the transportation infrastructure in its broadest sense is already well established (Banister \& Berechman, 2001; Barros, 2006).

Regions that have dense transportation infrastructure networks are better equipped to exchange resources and services, they have greater potential for economic growth, provided that those networks have proper trafficability conditions and that they connect strategic points within the spatial structure. It is also important to verify the efficient scaling of the circulation structure (Guerra, 2007; Voigt, 1960).

The impacts of transportation infrastructure should not be overlooked or neglected because they affect the economy directly, if you consider changes in accessibility and, indirectly, when you consider their multiplying effects (ESCAP, 2001; Araújo, 2006; Eberts, 2000). In the first case, accessibility reveals a region's potential in terms of flow capacity to convey goods and people. In the second case, transportation infrastructure tends to affect the most dynamic sectors of the economy, which, by means of the multiplying effects, generate income and employment (Resende, 2003; Almeida, 2011).

\subsection{Regional Economic Development Theories}

Political economy emerged in the eighteenth century as a response to the bourgeoisie's demand for a systematic explanation for the mechanisms of trade. Important names such as Adam Smith and David Ricardo developed the theoretical basis of that which is now called classical political economy. Classical economics consolidated the concepts of a strictly economic society, where individuals pushed the society's material progress without worrying about the problems that would be caused by the development process itself (Duke apud Almeida, 2008). Theories of regional development started to emerge only after the crisis of 1929 and World War II. These theories focused both on economic development and on the problems caused by the crisis (Almeida, 2011).

With the crisis, the issue of industrial concentration was considered harmful, given that unemployment and other effects it caused did not spread homogeneously across space, which created greater social problems in certain areas than in others. Economic recovery plans were required to take the element of space into consideration (Souza, 1981). Accordingly, scholars began to develop geo-economics theories, which increasingly dealt with the issues of location and space (Almeida, 2011). The works of François Perroux, Von Thünen, Weber and August Lösch must be highlighted. This study relies on the assumptions proposed by the last author.

\subsubsection{Lösch's Location Theory}

\subsubsection{Introduction}

According to Ramos and Mendes (2001), Lösch (1957) relates the works of the scholars who came before him and adds to their work with original and important materials. Lösch expands the issue of industrial location to the economic system as a whole and applies a general equilibrium theory that is still current. To develop the concept of what a set is, Lösch analyzes the location issue from the point of view of both the producer and the consumer. The basic assumptions of his model include the existence of an unbounded, homogeneous plain, where the transportation conditions and production costs are similar at any point. Accordingly, the population and raw materials are evenly distributed over that plain. Furthermore, locations must be so numerous that the entire space is fully occupied. Lösch assumes that consumers have identical preferences, and those located on bordering areas are considered indifferent to neighboring producers when it comes to buying consumer goods (Breitbach, 1998).

\subsubsection{Formal Model of Lösch's Location Theory}

Space configured based on those assumptions constitutes a market area especially monopolized by a single producer of a particular good. Mathematically, Lösch demonstrates that each market area assumes a cone shape, also called demand cone, so that it allows for both the greatest number of sales, and for satisfying all customers with the least distance friction possible. The best location is a function of the spatial differences between supply and demand; therefore, producers can make the most profit and consumers can shop at the lowest possible prices (Breitbach, 1998). Thus, there is the concept of market area (or demand cone) represented by Figure 1. 


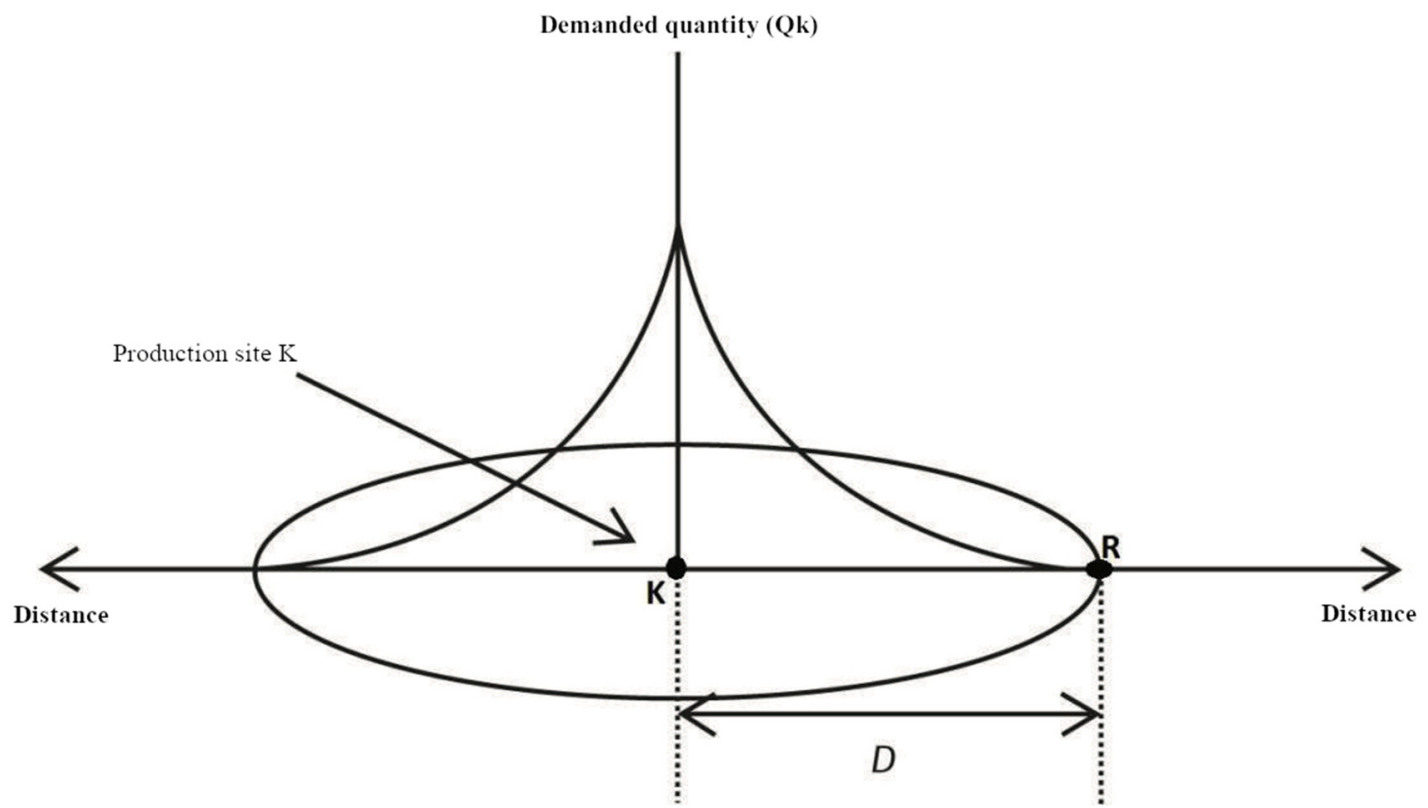

Figure 1. Representation of the market area (Lösch's Demand Cone)

Source: Mccann, 2013

The volume of the demand cone, corrected by population density, is equal to the total product demand in accordance with the equation (1):

$$
D=b \pi \int_{k}^{R} f(P+T) T d T
$$

Thus:

D: $\quad$ total demand product (maximum demand);

b: $\quad$ is twice the population density;

$\pi: \quad$ the ratio of a circle's circumference to its diameter (approximately 3.14..)

$\mathrm{R}$ : $\quad$ critical transportation cost when the demand quantity of the product is zero $(\mathrm{q}=0)$;

$\mathrm{P}$ : $\quad$ product manufacturing price;

$f(P+T)$ : individual demand;

$\mathrm{T}$ : $\quad$ transportation cost.

\subsubsection{Conceptual Aspects of Lösch's Location Theory}

This mechanism works as follows: there is a territory to be stocked with outputs from a production unit and the amount of goods to be sold is a direct function of price. In turn, the price varies according to the cost of transportation (distance). This is the boundary of the market area. As costs decrease, prices also fall, so that the bordering line moves, expanding the market area. This will be reduced when, for example, a production unit wants to expand its market area, supplying outputs to other consumption areas besides its own. In this case, transportation costs increase prices due to the great distance between producer and consumer. Higher product prices will suppress demand, which will, in turn, reduce the market area (Breitbach, 1998).

From Lösch's perspective, the market area will determine the choice of location (Maia, 2001). The best market area is achieved by means of minimum production and reduced transportation costs. The establishment of new market areas due to the arrival of new companies causes certain companies to overlap each other's market areas, consequently catering for shorter distances. This reduces transportation costs, thus, it reduces final prices. At equilibrium, production and transportation costs are identical for all companies and they will produce and sell the same amounts in the market (Souza, 1997). 
That being the theoretical mechanism on which Lösch supports his location model, the author realizes that, in reality, the perspective from a single economic unit does not exhaust the problematics of location. Lösch reckons that producers of similar or complementary goods have a close relationship concerning location. Within a freecompetition market, such a monopolistic hypothesis cannot last long because when a competing producer enters a certain market area, that will change the conditions initially proposed (Breitbach, 1998).

According to Mello and Mello (2009), with the work of Lösch (1957), companies' geographic expansion process in domestic and foreign markets can be explained by the formulation of the concept of market area. Lösch relates the market area concept to economies of scale, with increasing revenue and demand curves in space. When there is an increase in economies of scale, the company's overall supply in space also increases. Therefore, the concept of economies of scale, which begins and broadens the market area's formation process, can be understood as the concentration of production of the same product in larger production units, in order to reduce the unit transformation cost. The fact that Lösch included economies of scale in his spatial analysis is important because he deals with the growth of these economies as a central analytical element that structures the economic space.

Thus, taking into account the interaction between different factors, Lösch formulated his general equilibrium theory. By introducing the idea that multiple markets of different goods and of various sizes can overlap, Lösch created the market area network, whose production centers are interconnected to one another by means of a transportation network. The idea of market area networks has the notion of agglomeration; that is, the overlapping of different networks leads supply centers to coincide with higher demand, which thereby benefits certain production centers instead of others (Breitbach, 1998).

Particular locations are determined according to the situation of production factors, on the part of both competitors and consumers. These locations influence each other by means of the impact they have on supply and demand levels and, therefore, on the nature and form of economic activities. Individual locations are determined by the pursuit of maximum individual profit; those relationships lead to the equalization of the economic units' benefits and to the maximization of the number of independent units (Ramos \& Mendes, 2001).

This is why particular combinations arise between production and consumption centers. These combinations are called partial markets, which are a subdivision of the global market. There are two types of partial markets: 'supply areas', which occur in agricultural locations, and 'extraction areas', which occur in industrial locations. Lösch defines 'supply areas' as a scenario where many producers regroup around a consumption center, and 'extraction areas' as a situation when many consumption centers regroup around a producer (Ramos \& Mendes, 2001).

No matter how many production units there are in a given region, what counts are the number and the position of locations: that is what determines the type of region. It is worth noting that the number of production units is generally larger in agricultural settings than in industrial ones. These locations may be scattered around or agglomerated. In addition, the concentrations themselves may consist of punctual regroupings or regroupings by zones. In the first case, market areas overlap; whereas in the second, they are juxtaposed and their boundaries correspond to lines or land strips, according to the competing locations' strengths and to the variety of products (Ramos \& Mendes, 2001).

Lösch then analyzed the features that should distinguish agricultural locations from industrial locations. In the case of industry, costs (transportation costs, production costs and the relationship between them) and revenues (value and purchasing power of customers, price levels). Even though these factors can be used to explain the actual locations, the best location, on the other hand, depends on net profit. However, after learning about the close interdependence relationship between price, demand and location, Lösch was not able to design a general formula to determine the best location because there are too many variables involved. The only possible solution is to find, for each virtual industrial location, the total possible demand and the desirable production volume, as a function of cost (Ramos \& Mendes, 2001).

According to Lösch, urban centers are point agglomerations whose locations are non-agricultural; and this formation is explained by five sets of factors (Ramos \& Mendes, 2001):

- The benefits of large-scale production can lead big companies to concentrate in a certain place;

- Companies of the same type can be led to agglomerate by means of attraction to external economies; because of technical advantages of a given region regarding the production process, or also due to the increased possibility of competition;

- Heterogeneous companies can geographically come near each other due to their interdependence linkages;

- Urban centers can emerge from the simple agglomeration of consumers; 
- It is important to add the historical factor which contributed that agglomerations take place around pre-existing sources of supply: raw materials, energy sources, workforce or capital.

Lösch's Location Theory plays a central role in analyzing the relationship between transportation and economic development, given that the factors involving transportation costs are taken into account in the process of choosing the best location and establishing a market area.

3. Theoretical Model Proposed to Feature the Relationship between Transportation Infrastructure and Economic Development based on Lösch's Location Theory

As presented earlier, transportation infrastructure plays a central role in the process of economic development because it is only after there is transportation infrastructure that a region is able to have more commercial relationships and achieve greater development levels. However, this relationship is not direct. The steps that should be taken from implementing transportation infrastructure to achieving economic development are illustrated by the flowchart in Figure 2. 


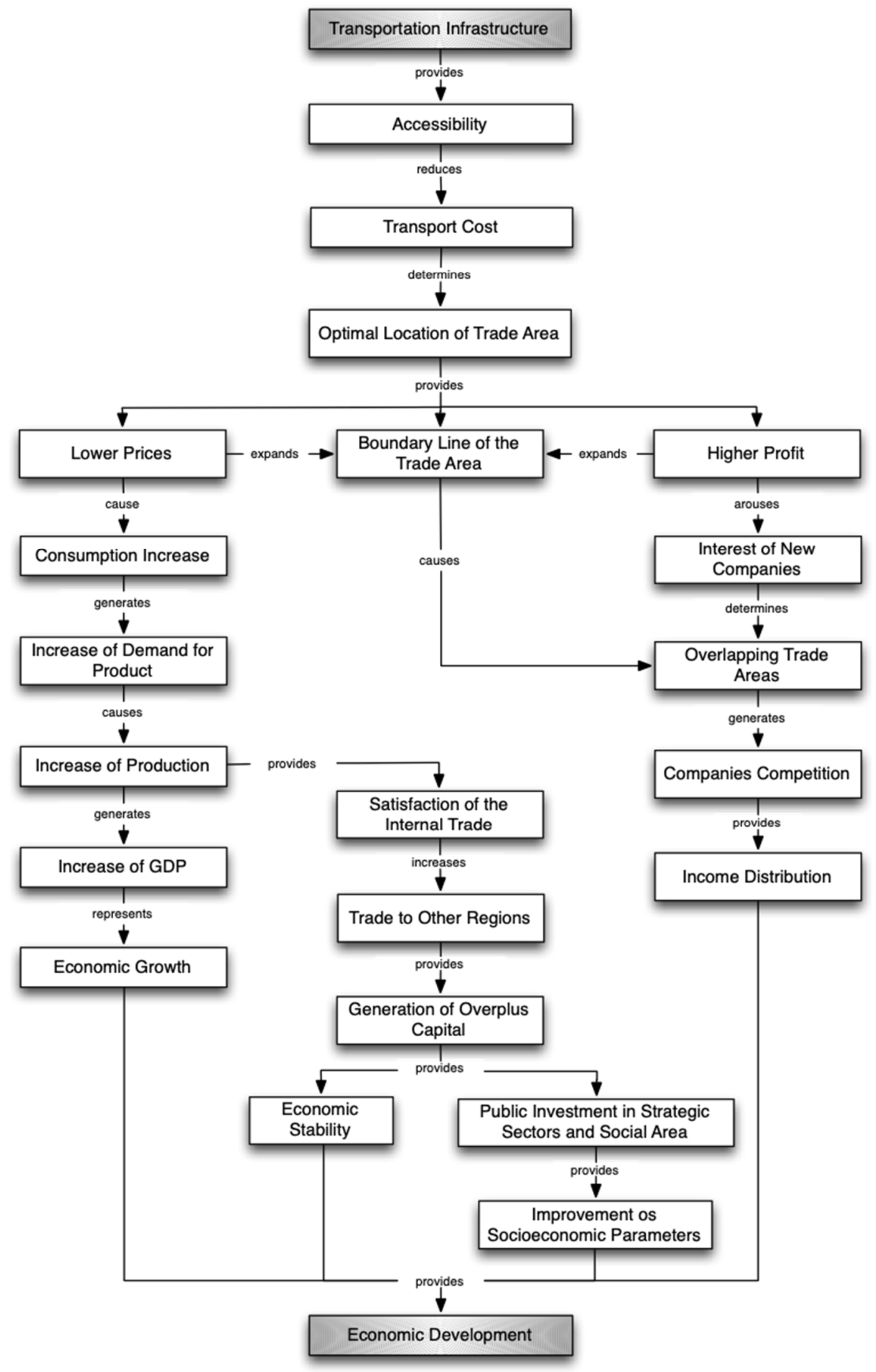

Figure 2. Theoretical model to feature the relationship between transportation infrastructure and economic development 
It is worth highlighting that some conditions should be observed in order to achieve the ultimate goal which is economic development. Banister and Berechman (2001) state that investment in transportation infrastructure will only become economic development if economic, political-institutional and investment conditions act simultaneously. It is understood that a region needs to have transportation infrastructure in order to achieve economic development. However, having transportation infrastructure alone is not enough to ensure that economic development will take place (Barros, 2006).

Improving transportation pathways makes it easier for regions to interact spatially and have more commercial relationships, which causes the regions to attract each other. An accessible region is interesting for companies that can quantify the monetary cost between two regions. Besides, when a region is accessible, transportation costs are greatly reduced. Choosing the efficient modes of transportation and transportation pathways, taking into account the region's needs and availability of natural resources, leads to a higher flow of goods with low transportation costs, given that it promotes a better outflow of products because distances are shortened.

According to Lösch's Location Theory, transportation costs play a key role when a company is choosing the best location for a market area. The best market area is the region in which transportation costs still cater for reduced product prices and profit yielding. It is worth highlighting that, when dealing with a developing region, it is important to improve transportation pathways and modes to reduce transportation costs because this will establish a better market area; thus, product prices will be reduced, higher profits will be achieved and the market area will be expanded. Moreover, this will call the attention of new companies, which may settle in the region and, consequently, resize the market areas in such a way that overlapping may occur. The overlapping of market areas will result in competition between companies and, thus, in income distribution.

If a region is difficult to access due to its geographical isolation and poorly maintained roads, producers of different goods will have a monopoly of the goods sold as a result of the absence of competition. These producers will raise product prices, yielding higher profits and keeping the regional population with low income rates.

This vicious circle can be broken by building new transportation pathways as a way of linking the region to major centers. By making the region more accessible and allowing for the arrival of new producers, the former monopoly will be broken. With the end of monopoly, products will no longer be overpriced and the profit will be transferred to the population, who will be able to use those resources to purchase services that were not accessible to them before. Another effect of the competition between companies on income distribution is the demand for workforce, which will result in higher salaries and, therefore, in increased income distribution.

When prices are reduced, this obviously triggers greater consumption levels and, consequently, increases demand for products in order to meet the need of the economy. This requires production levels to grow, which, in turn, increases GDP and, hence, promotes economic development.

On the other hand, given the increase in production and considering the ease of access between locations in the region under study, which has transportation infrastructure, it is possible to satisfy the domestic market's needs and, from there, increase trade to other regions. This will generate capital surplus, which will result in economic stability and could be turned into public investment in strategic sectors, which will consequently improve the socioeconomic parameters.

If a given region achieves economic development, economic stability, fair income distribution and improvement in socioeconomic development indicators, this means that the population of the region has higher standard of living and that, consequently, the region is developed.

\section{Empirical Methodology to Analise the Relationship between Investment in Transportation Infrastructure and Economic Development}

In this section the relationship between investments in transportation infrastructure and economic development was evaluated using econometric procedures. These econometric procedures are, specifically, multivariate time series techniques and models. The main idea is to evaluate the endogenous relation between the variations of GDP and the spatial shocks of investments in transportation infrastructure (Pradhan \& Bagchi, 2013; Kulshreshtha \& Kulshreshtha, 2001; Ramanathan, 2001).

According to the presented theory it is assumed that spatial factors are important to estimate the effects of transportation infrastructure on development. Thus, in addition to the impact of this type of investment on the GDP, it was estimated whether the investments made in the federative units (states and the federal district) have any overflow effect on the vicinity. For this purpose, the Spatial Panel Auto Regressive Vector Model (PVAR) was used. The next subsections present the details of the spatial PVAR model, the data used, its sources and the estimation results. 


\subsection{Spatial Panel Auto Regressive Vector Model}

Autoregressive Vector (VAR) models emerged to estimate macroeconomic problems and were an alternative approach to simultaneous equations (Sims, 1980). The VAR model is a system of discrete equations and all variables are endogenous. However, in this paper the VAR model was estimated for a spatial data panel.

The proposal is to investigate whether investments in transportation infrastructure have an impact on GDP in Brazil. In addition, we intend to test the overflow effect between the Brazilian regions. Therefore, a data panel was used for the period from 2006 to 2013. A similar study was that of Bertussi and Ellery Jr. (2006) who used a panel of fixed effects and quantiles regressions.

The advantage of the model used in this paper is that it tests for the presence of endogeneity between investments and GDP variances, as well as dealing with the problem of endogeneity with dynamic variables (Anderson and Hsiao, 1982). After all, the PVAR Space is estimated using the Generalized Moments Method (GMM) (Arellano and Bover, 1995). By this approach the Losch theory variables are incorporated measuring the effects of transportation infrastructure on development conditioned by a cone shape demand distance using the PVAR Space model, but the variables in Losch theory are not directly incorporated.

In this context, a Panel VAR with $k$ variables and order $p$ is considered. This model is specified by fixed effects and represented by the following system of linear equations:

$$
\begin{gathered}
G D P_{t}=\alpha_{01}+\alpha_{11} I N V T_{t}+\alpha_{21} I N V T_{t-1}+\cdots+\alpha_{k 1} I N V T_{t-k}+\beta_{11} G D P_{t-1}+\beta_{21} G D P_{t-2}+\cdots+\beta_{l 1} G D P_{t-l}+ \\
\theta_{11} N e i b+e_{i 1}+\varepsilon_{i t 1} \\
I N V T_{t}=\gamma_{02}+\gamma_{12} G D P_{t}+\gamma_{22} G D P_{t-1}+\cdots+\gamma_{k 2} G D P_{t-m}+\delta_{11} I N V T_{t-1}+\delta_{21} I N V T_{t-2}+\cdots+\delta_{l 1} I N V T_{t-n}+ \\
\theta_{12} N e i b+e_{i 2}+\varepsilon_{i t 2}
\end{gathered}
$$

where GDP is the annual changes in GDP, INVT is the expenditure on transportation infrastructure in year $t$ and in unit of the federation $i$. All variables were lagged until year $k, l, \operatorname{mandn.} \alpha, \beta, \gamma a n d \delta$ re sets of parameters to be estimated. $\varepsilon_{i t 1}$ and $\varepsilon_{i t 2}$ are the random errors of each equation, while $e_{i 1}$ ande $e_{i 2}$ are the fixed effects components.

It is assumed that the error components have averages equal to zero, $E\left(\varepsilon_{i t}\right)=0$, absence of serial correlation, $E\left(\varepsilon_{i t}^{\prime} \varepsilon_{i t}\right)=\Sigma$, and absence of spatial correlation, $E\left(\varepsilon_{i t}^{\prime} \varepsilon_{i s}\right)=0$. All the parameters incorporated in the model can be estimated together with fixed effects. Despite the lagged dependent variables, estimates would be biased even in large samples (Nickell, 1981). However, the bias tends to zero as the sample increases. According to Judson and Owen (1999), although the bias tends to be zero, it exists for samples with degrees of freedom greater than 30 . In order to correct for these possible biased estimators, the Generalized Moments Method (GMM) was adopted to estimate the system expressed by equations 2 and 3 . The GMM method is not the only one able to correct the bias of the OLS estimators. That is also the case of the OLS model with dummy variables and Bootstrap resampling (Kiviet, 1995; Evereat and Pozzi, 2007).

According to Anderson and Hsiao (1982), the first difference transformation can be consistently estimated, equation by equation. From differentiated and lagged instruments with different levels of $y_{i t}$ periods, the GMM estimate generates estimates in a VAR panel (Holt-Eakin, Newey and Rosen, 1988).

Arellano and Bover (1995) proposed an orthogonal deviation as an alternative transformation to a first difference. For example, the $G D P_{i t}$ dependent variable was calculated as $G D P_{i t}^{*}=\left[\left(G D P_{i t}-G D P_{i t-1}\right) / \sqrt{T_{i t} / T_{i t+1}}\right]$, where $T_{i t}$ is the number of future observations available to the panel. If panels are pooled over time, the GMM estimator is given by $\left.A_{G M M}=G D P_{i t}^{* \prime} I N V_{i t} \hat{W} I N V_{i t}^{\prime} G \bar{D} P_{i t}^{*}\right)^{-1}\left(G D P_{i t}^{*} I N V_{i t} \hat{W} I N V_{i t}^{\prime} G D P_{i t}^{*}\right)$. In this estimator $\mathrm{W}$ is a matrix of non-singular, symmetric and positive semi-defined weights. The joint estimation conducts the Wald Parameters test and the Granger causality test as well as the creation of the Impulse and Response Functions (IRF) and Forecast-error variance decomposition (FEVD). 


\subsection{Data, Data Sources and Variables}

To explore growth between investment and investment in infrastructure and resources, data from the Institute of Applied Economic Research (IPEA) and the Brazilian National Treasury were used. The data were selected for the 26 Brazilian states and for the Federal District, from 2006 to 2013, according to the availability of the information.

State GDP was expressed in annual variations as proxy for the economic growth of each unit of the Brazilian federation. As the state's GDP, the transportation investment variable was also expressed in logarithmic form, for the purpose of calculating the annual variations.

\subsection{Results and Discussion}

The objective of the econometric estimation is to explain the relationship between state expenditure on transportation and regional economic growth. To estimate this relationship, a VAR model was used in Dynamic Panel (Pradhan \& Bagchi, 2013). In this approach, the basic characteristic is the endogeneity between Transportation Expenditures (TE) and GDP Growth (GDP) in the states. It is assumed that TE explains the variations of state GDP, just as GDP can cause TE. The results of the estimation in GMM are expressed in Table 1.

Table 1. Estimated autoregressive vector models

\begin{tabular}{|c|c|c|c|c|c|c|c|}
\hline \multirow[b]{2}{*}{ Variable } & \multicolumn{7}{|c|}{ Dependet Variable } \\
\hline & $\begin{array}{l}\text { Log_PIB } \\
\text { Cofficient } \\
\text { Std. Err.) }\end{array}$ & $\begin{array}{l}\text { Log_Gst_Transp } \\
\text { Cœfficient } \\
\text { Std. Err.) }\end{array}$ & $\begin{array}{c}\text { Neib_loggtransp (N) } \\
\text { Cœfficient } \\
\text { (Std. Err.) }\end{array}$ & $\begin{array}{c}\text { Neib_loggtransp (S) } \\
\text { Cœfficient } \\
\text { Std. Err.) }\end{array}$ & $\begin{array}{c}\text { Neib_loggtransp (NE) } \\
\text { Cœefficient } \\
\text { Std. Err.) }\end{array}$ & $\begin{array}{c}\text { Neib_loggtransp (SE) } \\
\text { Cœfficient } \\
\text { (Std. Err.) }\end{array}$ & $\begin{array}{c}\text { Neib_loggtransp (CW) } \\
\text { Cœffidient } \\
\text { (std. Err.) }\end{array}$ \\
\hline $\log p i b(1)$ & $\begin{array}{c}0.1083 \\
(0.0788)\end{array}$ & $\begin{array}{c}0.2812^{* * *} \\
(0.0573)\end{array}$ & $\begin{array}{c}1.8401^{* * *} \\
(0.2076)\end{array}$ & $\begin{array}{c}2.701^{* * *} \\
(0.3004)\end{array}$ & $\begin{array}{c}1.1021^{* * *} \\
(0.0913)\end{array}$ & $\begin{array}{c}3.9103^{* * *} \\
(0.0823)\end{array}$ & $\begin{array}{c}3.925^{* * *} \\
(0.3909)\end{array}$ \\
\hline $\log g s t t r a n s p(1)$ & $\begin{array}{l}-0.1748^{*} \\
(0.2231)\end{array}$ & $\begin{array}{c}0.4516^{* * *} \\
(0.1594)\end{array}$ & $\begin{array}{c}1.0743 * * * \\
(0.0981)\end{array}$ & $\begin{array}{c}1.8098^{* * *} \\
(0.1107)\end{array}$ & $\begin{array}{c}2.7811^{* * *} \\
(0.1281)\end{array}$ & $\begin{array}{c}3.0611^{* * *} \\
(0.0810)\end{array}$ & $\begin{array}{c}2.5715^{* * *} \\
(1.4906)\end{array}$ \\
\hline Neib_loggtran $\$$ (1) (N) & - & - & $\begin{array}{l}0.0210^{* *} \\
(0.01077)\end{array}$ & - & - & - & - \\
\hline Neib_loggtran $\$$ (1) (S) & - & - & - & $\begin{array}{c}0.1559^{* * *} \\
(0.0862)\end{array}$ & - & - & - \\
\hline Neib_loggtran $\$(1)$ (NE) & - & $\cdot$ & - & - & $\begin{array}{c}0.0510^{* *} \\
(0.0916)\end{array}$ & - & - \\
\hline Neib_loggtransp(1) (SE) & - & - & - & - & - & $\begin{array}{c}0.0917^{* * *} \\
(0.0710)\end{array}$ & - \\
\hline Neib_loggtran $\$(1)(C W)$ & $\begin{array}{l}0.1035^{* *} \\
(0.01266)\end{array}$ & $\begin{array}{c}0.0299^{* * *} \\
(0.0099)\end{array}$ & - & - & - & - & $\begin{array}{c}-0.0900^{*} \\
(0.0631)\end{array}$ \\
\hline
\end{tabular}

Source: authors' compilation, 2008.

Note: $* * * * *$ and $*$ signal statistically significant coefficients at $10 \%, 5 \%$ and $1 \%$.

According to the results of Table 1, from a lag model, it was verified that State Expenditure on Transportation influences the economic growth of the Brazilian states. Although not interpretable, the results were statistically significant. Regarding endogeneity, it was noticed that the fact that the states grow economically also influences the spending of the State Governments on Transportation.

According to the proposed theoretical model, the mechanisms that promote regional economic growth influenced by investments in transportation are: a) reduction of transportation costs; b) reduction of prices, and; c) higher profits. These mechanisms, through transportation costs, promote economic stability and more public investment, leading to regional economic development.

Statistical tests of the neighborhood effect were incorporated in the econometric estimation. In Table 1 the neighborhood effect was statistically significant in all Brazilian regions. Basically, when the Brazilian States invest in transportation, it influences the economic growth of the border states. This effect is explained by the fact that Brazilian production is transported from the center of the country to the ports. This transportation is marked by the 
connection between several modes of transportation, including by different infrastructures. In the same way as the state economic growth in Brazil is heterogeneous, the degree of development of the transportation infrastructure is as well. Therefore, all the problems faced in the logistics of Brazilian production reflect local development, especially when it comes to state highways.

According to standard procedures for the estimation of VAR models in panel, the decomposition of the error prediction variance and the Impulse-Response Functions are estimated. All these results are set out in Table 2 and Figure 3.

The results of the estimation revealed that transportation spending in the Brazilian states influences regional GDP growth for up to eight years. This effect is increasing from the second year and stable from the fourth year. The main explanation for this stability is the fact that transportation infrastructure expenditures require reinvestment.

Table 2. Decomposition of the prediction error variance of the estimated panel VAR models

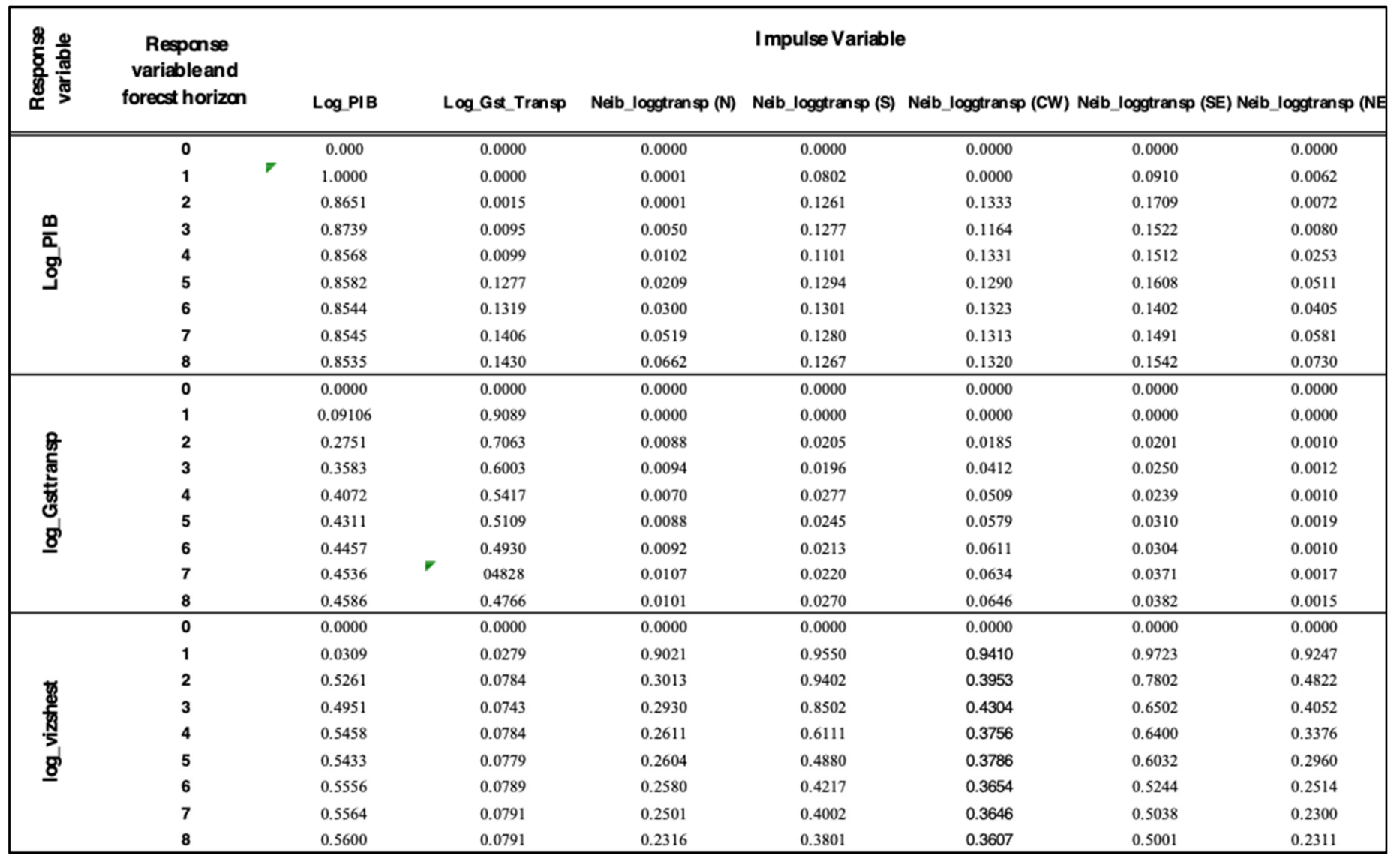

Source: authors' compilation, 2008.

Table 2 shows the influence of state transportation expenditures on a Brazilian region. The neighborhood test was repeated for the five Brazilian regions and it was verified that the effect is positive. It is noted that this effect is heterogeneous in magnitude, more intense in the Southeast and South, and less intense in the north and northeast regions of Brazil. Another important fact is to verify that the economic growth of the neighboring states promotes even more economic growth in the state where transportation expenses originated.

In general, regarding the neighborhood effect, it was noted that about $3 \%$ of the variations in the GDP of a region can be due to the influence of the transportation expenditures of neighboring states. It should be noted the magnitude of this effect is greater in the Southeast states and that can be caused by the border with more regions and also by local economic potentialities. In the case of the North, not even 1\% of GDP changes are explained by neighboring transportation infrastructure spending.

In Figure 3, the Impulse-Response Functions show the persistence and duration of these state investment shocks in transportation and its neighborhood effects. Like the estimated results for the decomposition of variance, in the 
impulse-response functions, transportation investment expenditures are more intense and last up to eight years, after which new investments are required. When this effect is decomposed by Brazilian regions, the results are more persistent in the Central-West region, the one totally dependent on the national logistics to transport agribusiness production.

In the Central-West region, the effect of transportation expenses on state GDP has a positive and increasing effect in the first years, and from the fourth year onwards, the effect of transportation investments returns to the initial level. Again, the need for continuous reinvestment is proven to influence regional economic growth.

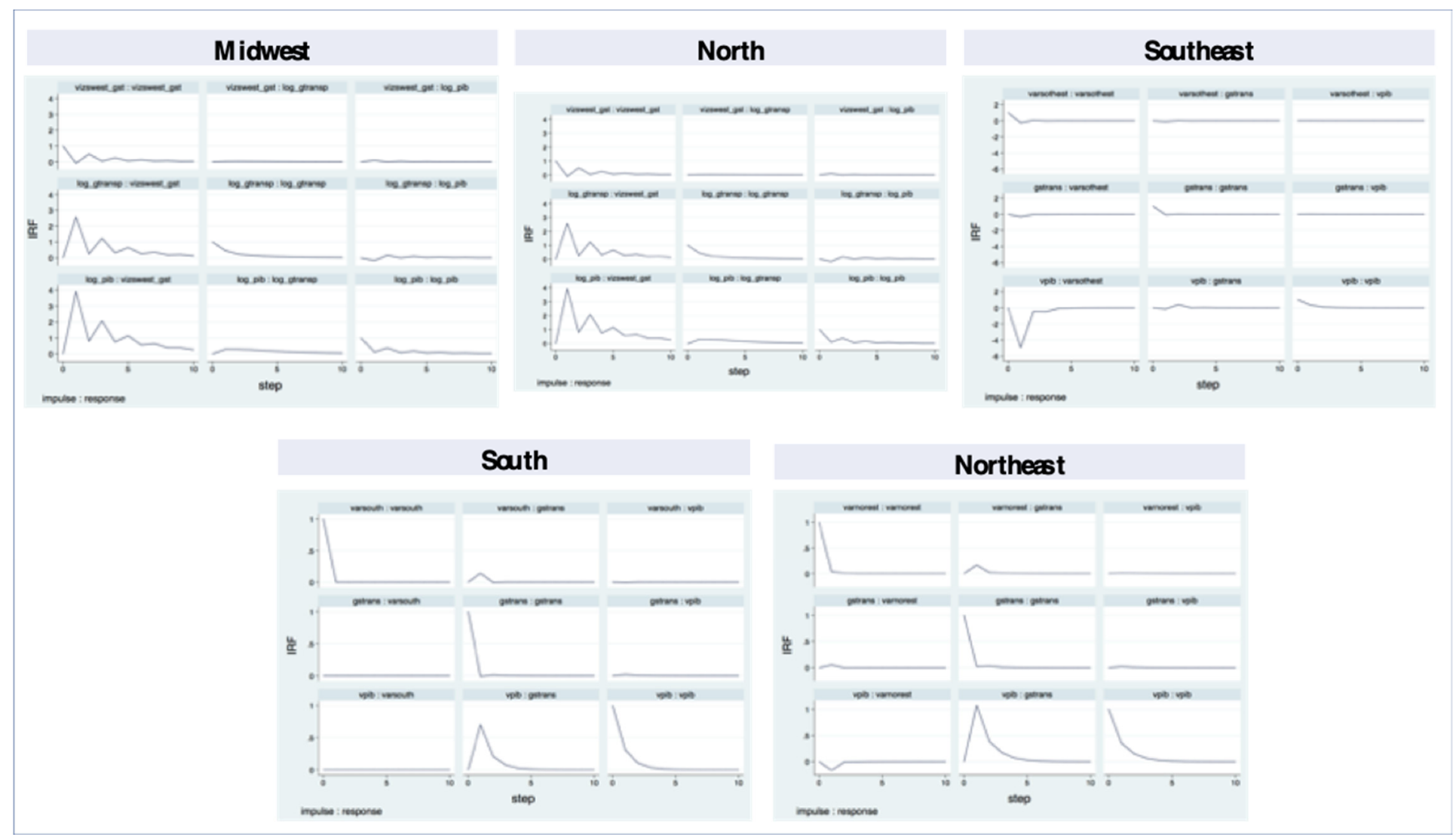

Figure 3. Impulse-response functions of the estimated panel VAR models

Source: authors' compilation, 2008

According to the specialized literature, estimates of a VAR model are rarely interpreted. Often, after estimating this class of econometric models, it is necessary to validate the interpretation of the FEVD and the impulseresponse functions. This validation is done by the estimated VAR stability condition. Thus, according to Figure 4, the Eigenvalue graphs confirm that the estimate is reliable. 


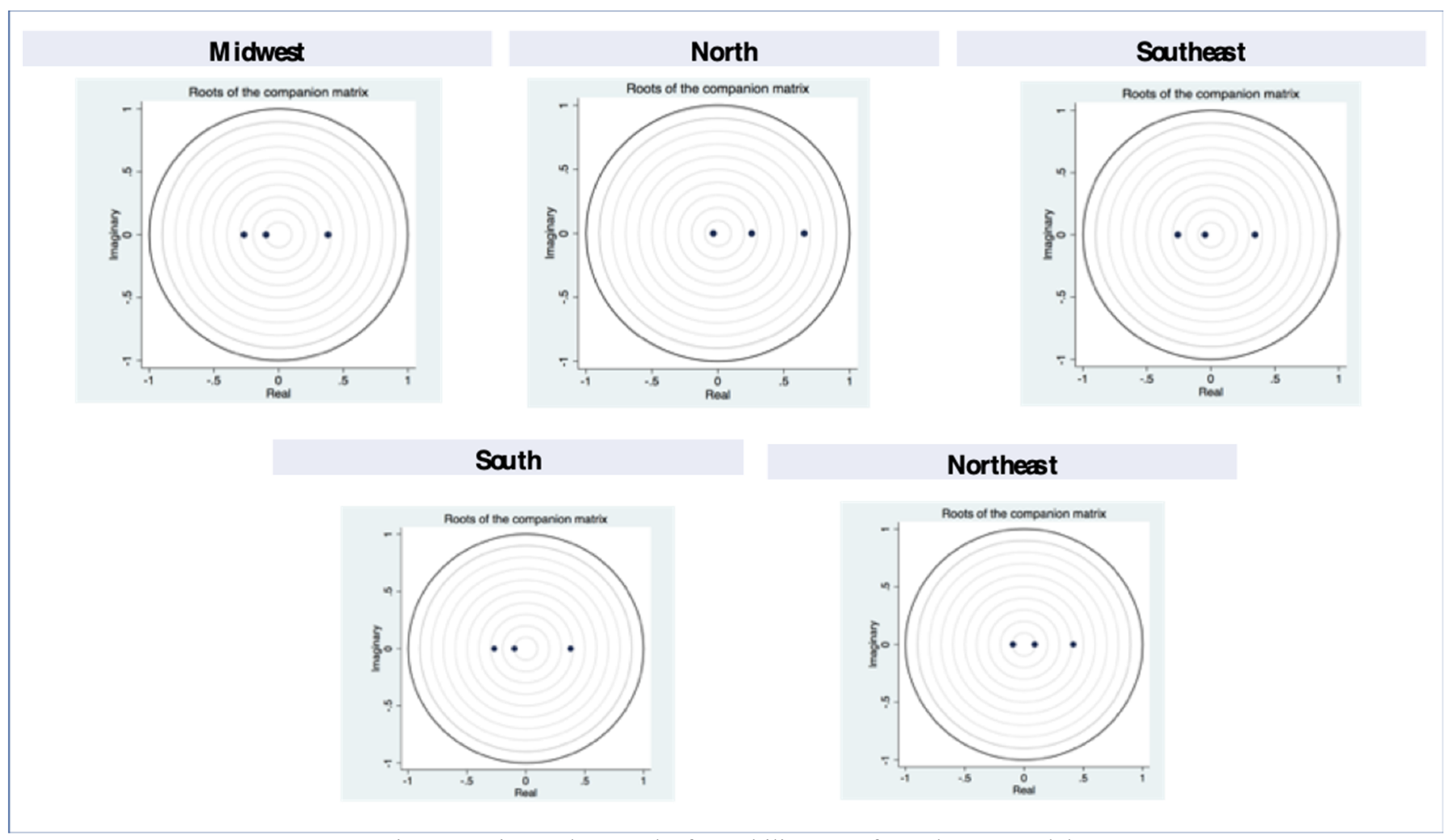

Figure 4. Eigenvalue graphs for stability test of panel VAR model

Source: authors' compilation, 2008

The respective graphs confirm that the real and imaginary roots of the forecast are stable and are statistically reliable. The tests were repeated for each estimated regional model and, in all, stability predictions were proved. This result can be observed because the roots do not extrapolate the real field of prediction.

\section{Conclusions}

The main objective of this paper was to evaluate the effect of investments in transportation infrastructure on Brazilian economic development. The study developed a methodological strategy for theoretical and empirical mechanisms. The relationship between economic performance, measured by the GDP growth was related to spending on transportation infrastructure in the Federative Units.

From the theoretical point of view, three channels of economic development were established. Through these mechanisms, it was established that investments in transportation infrastructure promote cost reduction, expansion of the borderline and profit making. The results are direct on economic growth, excess capital formation and income distribution. Thus, the interaction of these channels results in economic development.

Through the empirical approach, it was observed that spending in the Brazilian Federative Units generates local economic growth. It was also found that there is a spillover effect, specifically that investments in transportation infrastructure cause economic growth in neighboring units of the Federation. In addition, econometric tests pointed to an endogenous relationship between economic growth and investment in transportation infrastructure conditioned to spatial characteristics by PVAR model. Besides the importance to the local economy, it was verified that the economic performance of the federative units are also important levers of investments in transportation infrastructure. In regional terms, investment in transportation infrastructure is more intense in the Federative Units of the Midwest, certainly due to the logistic dependence of agribusiness.

It is important to highlight the following limitation of the study:

- The body of knowledge on transportation has gaps regarding how transportation infrastructure influences economic development, especially about the economic impacts that occur due to the building of infrastructure in a given region. Those impacts have not been measured or characterized. 
This paper contributes to the economic discussion of investments in transportation infrastructure and its effects in Brazil. The theoretical contribution explains the complexity of the mechanisms of this investment in the promotion of economic development in the country. On the other hand, the empirical methodology advances to tests of endogeneity, investment dynamicity and overflow effects. However, the following recommendations can guide future studies on the topic:

- Advancement of economic development measures in the analysis of the relationship between investment in transportation infrastructure and economic development conditioned to distance factor and in line with the government spending as a complement, as in Aschauer (1988) but in a microeconomic approach;

- Sensitivity analysis considering the spillover effect that investments in transportation infrastructure cause economic growth in neighboring units of the Federation.

\section{References}

Almeida, C. F. (2008). Elaboração de rede de transporte multimodal de carga para a região amazônica sob o enfoque de desenvolvimento econômico. Ph.D. Thesis (Transportation), Universidade de Brasília, Departamento de Engenharia Civil e Ambiental, Brasília, Brasil. (in Portuguese)

Almeida, C. F. (2012). Elaboração de rede de transporte multimodal de carga para a região amazônica sob o enfoque de desenvolvimento econômico. Tese de doutorado em transportes, Universidade de Brasília, Departamento de Engenharia Civil e Ambiental, Brasília, Brasil.

Araújo, M. P. (2006). Infraestrutura de transporte e desenvolvimento regional: uma abordagem de equilíbrio geral inter-regional. Ph.D. Thesis, Universidade de São Paulo, Escola Superior de Agricultura "Luiz de Queiroz", Piracicaba, Brasil. (in Portuguese)

Arrow, K. J. (1962). The economic implications of learning by doing. Review of Economic Studies, 29, 155-173. https://doi.org/10.2307/2295952

Aschauer, D. A. (1988). Government spending and the falling rate of profit. Economic Perspectives, 12, 11-17.

Aschauer, D. A. (1989a). Is Public Expenditure Productive? Journal of Monetary Economics, 23(2), 177-200. https://doi.org/10.1016/0304-3932(89)90047-0

Aschauer, D. A. (1989b). Is government spending productive? Journal of Monetary Economics, 23, 177-200. https://doi.org/10.1016/0304-3932(89)90047-0

Aschauer, D. A. (1989c). Does public capital crowd out private capital? Journal of Monetary Economics, 24, 171188. https://doi.org/10.1016/0304-3932(89)90002-0

Aschauer, D. A. (1989d). Public investment and productivity growth in the Group of Seven. Economic Perspectives, 13(5), 17-25.

Banister, D., \& Berechman, Y. (2001). Transport Investment and the Promotion of Economic Growth. Journal of Transport Geography, Pergamon, 9(3), 209-218. https://doi.org/10.1016/S0966-6923(01)00013-8

Barros, J. M. A. M. (2006). Infraestrutura de Transporte e Desenvolvimento - Interações e Complexidades. Ph.D. Thesis, Universidade Federal do Rio de Janeiro, Brasil. (in Portuguese)

Breitbach, A. C. M. (1998). Estudo Sobre o Conceito de Região. Secretaria de Coordenação e Planejamento, Fundação de Economia e Estatística, Porto Alegre, Brasil. (in Portuguese)

Calderón, C., \& Servén, L. (2003). The Output Cost of Latin America's Infrastructure Gap. In W. Easterly, \& L. Servén (Eds.), The Limits of Stabilization: Infrastructure, Public Deficits, and Growth in Latin America. Stanford University Press and the World Bank.

Calderón, C., Easterly, W., \& Servén, L. (2003). Infrastructure Compression and Public Sector Solvency in Latin America. In W. Easterly, \& L. Servén (Eds.), The Limits of Stabilization. Infrastructure, Public Deficits, and Growth in Latin America. Stanford University Press. https://doi.org/10.1596/978-0-8213-5489-6

Cândido Júnior, J. O. (2006). Efeitos do Investimento Público sobre o Produto e a Produtividade: uma análise empírica. Texto para Discussão ${ }^{\circ} 1204$. Brasília: IPEA.

Colman, D., \& Nixson, F. (1981). Desenvolvimento Econômico: uma Perspectiva Moderna. Tradução (de) Economics of Change in Less Developed Countries, Maria Célia Ramalho Pinto Guedes. Editora da Universidade de São Paulo, Brasil. (in Portuguese)

Cunha, A. M., Simões, R. F., \& Paula, J. A. (2008). História econômica e regionalização: contribuição a um desafio teórico-metodológico. Estudos Econômicos. Instituto de Pesquisas Econômicas, v. 38, p. 493-524. (in 
Portuguese). https://doi.org/10.1590/S0101-41612008000300003

Dasgupta, P., \& Stiglitz, J. E. (1988). Learning-by-Doing, Market Structure and Industrial and Trade Policies. Oxford Econ. Papers 40 (June 1988): 246-68. https://doi.org/10.1093/oxfordjournals.oep.a041850

Eberts, R. (2000). Understanding the impact of transportation on economic development. Retrieved from http://www.nationalacademies.org/trb/publications/millennium/00138.pdf

ESCAP - Economic and Social Commission for Asian and the Pacific. (2001). Review of Development in Transport in Asian and the Pacific. New York, USA.

Filho, B., Cândido, J. R., \& Pereira, F. (1999). Investimento e financiamento da infraestrutura no Brasil: 1990/2002. Brasília, Brasil. (in Portuguese)

Guerra, H. O. (2007). Análise para o Desenvolvimento de um Sistema de Gerência de Bancos de Dados Geográficos de Infraestrutura de Transportes. M.Sc. Dissertation, Universidade de Brasília, Faculdade de Tecnologia, Departamento de Engenharia Civil e Ambiental, Brasília, Brasil. (in Portuguese)

Haynes, K. (1997). Infrastructure. Journal of Transport Geography, 5(1), 23-24. https://doi.org/10.1016/S09666923(96)00045-2

Kulshreshtha, M., Nag, B., \& Kulshreshtha, M. (2001). A multivariate cointegrating vector auto regressive model of freight transport demand: evidence from Indian railways. Transport Research Part A, 35, 29-45. https://doi.org/10.1016/S0965-8564(99)00046-4

Lazana, A. E. T. (2004). O Setor Externo da Economia Brasileira. Em: PINHO, D. B. (in Portuguese)

Lösch, A. (1957). Teoría Económica Espacial. Librería "El Ateneo" Editorial Florida 340, Córdoba, Buenos Aires, Argentina.

Magalhães, J. P. A. (1996). Paradigmas Econômicos e Desenvolvimento: A Experiência Brasileira. Rio de Janeiro, EDUERJ: Ed. UFRJ. (in Portuguese)

Maia, M. F. R. (2001). A importância da Indústria Têxtil no Desenvolvimento do Município de Montes Claros. M.Sc. Thesis, Universidade Federal de Minas Gerais, Faculdade de Ciências Econômicas, Centro de Desenvolvimento e Planejamento Regional, Brasil. (in Portuguese)

Mccann, P. (2013). Modern urban and regional economics (2nd ed.). Oxford: Oxford University Press.

Mello, J. A. V. B., \& Mello, A. J. R. (2009). Fundamentos de Localização sob a Perspectiva do Consumo nas Cidades. In: Simpósio de Excelência em Gestão e Tecnologia - SEGET, 2009, Resende. VI Simpósio de Excelência em Gestão e Tecnologia. (in Portuguese)

Oliveira, J. C. (2008). Análise do Crescimento Econômico e das Desigualdades Regionais no Brasil. Estudos do CEPE, Revista do Departamento de Ciências Econômicas, Ed.UNISC, Santa Cruz do Sul, Brasil. (in Portuguese)

Pradhan, R. P., \& Bagchi, T. P. (2013). Effect of transportation infrastructure on economic growth in India: The VECM approach. Research in Transportation Economics, (38), 139-148. https://doi.org/10.1016/j.retrec.2012.05.008

Quinet, E. (1992). Infrastructures de Transport et Croissance. Paris, Ed. Econômica. (in Portuguese)

Ramanathan, R. (2001). The long-run behavior of transport performance in India: a cointegration approach. Transport Research Part A, 35, 309-320. https://doi.org/10.1016/S0965-8564(99)00060-9

Ramos, R. A. R., \& Mendes, J. F. G. (2001). Introdução às Teorias da Localização. Universidade do Minho, Departamento de Engenharia Civil. Guimarães, Portugal. (in Portuguese)

Ramsey, F. P. (1928). A Mathematical Theory of Saving. Econ. J. 38 (December 1928): 543-59. https://doi.org/10.2307/2224098

Resende, M. F. C. (2003). Troca Intertemporal Entre Economias Desenvolvidas e em Desenvolvimento, Texto para Discussão no. 201, Universidade Federal de Minas Gerais - UFMG/Cedeplar, Minas Gerais, Brasil. (in Portuguese)

Romer, P. M. (1986). Increasing Returns and Long-Run Growth. Journal of Political Economy, XCIV, 1002-1037. https://doi.org/10.1086/261420

Romer, P. M. (1990). Endogeneous Technological Change. The Journal of Political Economy, Vol. 98, No. 5, Part 2: The Problem of Development: A Conference of the Institute for the Study of Free Enterprise Systems (Oct., 
1990), pp. S71- S102. https://doi.org/10.1086/261725

Solow, R. M. (1957). Technical change and the aggregate production function. Review of Economics and Statistics, 3(3), 312-320. https://doi.org/10.2307/1926047

Souza, N. (1981). Economia regional: Conceitos e Fundamentos Teóricos. In: Perspectiva Econômica, Ano XVI, vol II, $\mathrm{n}^{\circ}$ 32. (in Portuguese)

Souza, N. (1997). Introdução à Economia. São Paulo: Atlas. (in Portuguese)

Swan, T. (1956). Economic Growth and Capital Accumulation. Economic Record, 32(3), 334-61. https://doi.org/10.1111/j.1475-4932.1956.tb00434.x

Théry, H., \& Mello, N. A. (2005) Atlas do Brasil: Disparidades e Dinâmicas do Território. Edusp, Editora da Universidade de São Paulo, São Paulo, Brasil. (in Portuguese)

Uzawa, H. (1965) Optimum technical change in an aggregative model of economic growth. International Economic Review, 6, 18-31. https://doi.org/10.2307/2525621

Voigt, F. (1960). The Importance of the Transport System for Economic Development Processes. Addis Abada, United Nations Economic Commission for Africa, E/CN. 14/CAP/39.

\section{Copyrights}

Copyright for this article is retained by the author(s), with first publication rights granted to the journal.

This is an open-access article distributed under the terms and conditions of the Creative Commons Attribution license (http://creativecommons.org/licenses/by/4.0/). 